International Journal of Engineering \& Technology, $7(4.34)(2018) 284-286$
International Journal of Engineering \& Technology
SPC
Website: www.sciencepubco.com/index.php/IJET
Research $p a$

\title{
The Influence of Business Strategy and Good Corporate Governance on Company's Performance
}

\author{
R. Ait Novatiani, Mohd Haizam Mohd Saudi*, R. Wedi Rusmawan Kusumah, Achmad Fajar, Rita Yuniarti
}

School of Graduate Studies, Widyatama University, Bandung, Indonesia

*Corresponding author E-mail: haizam@widyatama.ac.id

\begin{abstract}
In general purpose of a company is to look for the highest profit. An increase in profits shows the company's performance is good, to ensure that the company's performance is good, it must be supported by a business strategy and good corporate governance. The purpose of this study is to analyze business strategies and good corporate governance, both partially and simultaneously affect the company's performance. Sampling technique used in this study non probability namely census sampling which is 46 census sampling. Based on the results of the study, it can be concluded that business strategies and good corporate governance both partially and simultaneously influence the company's performance
\end{abstract}

Keywords: Business strategies; good corporate governance; company's performance.

\section{Introduction}

In general, the purpose of a company is to seek profits as highest profit, this accordance with what was stated [3]. That is established company increases its owner's wealth by increasing the value of the company. Company value can be achieved if the company can achieve a predetermined profit. An increase in profits shows the company's performance is good. This is in accordance with what was stated by [7] that is the company's performance is the result or achievement that is influenced by the company's operational activities in utilizing its resources. Company performance is a level of success that can be measured and seen, the extent to which a person's work can achieved company performance according to the target. The goals, vision and mission of the organization for a certain period of time. In 2016, there were companies whose performance decreased namely PT. Semen Indonesia Tbk. The results of the company's financial statements show PT. Semen Indonesia Tbk experienced in net income of $8,4 \%$ to 2,9 trillion compared to the same period last year of 3,34 trillion The decline in net income was in line with operating income which fell $0.16 \%$ to Rp. 19.08 trillion during January - September 2016. PT. Semen Indonesia, PT. Indocement Tunggal Prakasa Tbk also experienced a decrease in net profit of $2.2 \%$ to Rp. 3.14 trillion. This was due to a decline in company revenue by $12 \%$ to $\mathrm{Rp} .11 .34$ trillion from $\mathrm{Rp} .12 .88$ trillion previously. Followed by PT Semen Baturaja Tbk which recorded in its books that its net profit decreased by $3.4 \%$ to $\mathrm{Rp} .174 .7$ billion during January - September 2016, lower than the same period last year of Rp. 265 billion. Even so, in terms of revenue the company was able to strengthen slightly to $\mathrm{Rp} .1 .04$ trillion from the previous Rp. 1.03 trillion. Purwoko said that actual cement demand would increase in line with infrastructure projects being boosted by the government. However, the increase in demand is not comparable to the level of supply that hit the cement issuer (www.cnnindonesia.com).
The problems that occur above are a decrease in net profit from cement companies that occurs because cement companies cannot meet consumer demand which causes profit potential to decline and losses occur, increasing companies in the cement sector, the company must carry out strategies to maintain its business in order to improve company performance. The decline in profits shows that the company's performance is not good, for this reason, an adequate business strategy is needed. The business strategy focuses on improving the competitive position of a company or business unit product or service with a specific industry as well as the market segmentation of the company or service business unit. Business strategy is very important because it looks at how the business unit has an effect on the overall performance of the company [13]. The results of [1] show that corporate strategy can increase the opportunities and performance of the company. The results of other studies conducted by [8] show that there is an influence between business strategy, management techniques, accounting practices on company performance.

Other efforts that can improve the company's performance are by applying the principles of good corporate governance in every operational activity of the company with the aim of increasing value that can support the company's performance. This is in line with research conducted by [12] which states that theoretically good corporate governance practices can influence and improve company performance, reducing the risk that may be carried out by the board with favorable decisions and can increase investor confidence to invest. The results of research conducted by [11] show that the implementation of good corporate governance (GCG) that is good and in accordance with applicable regulations will encourage companies to improve company performance.

The principles of good corporate governance (GCG) have a purpose to provide performance for the progress of a company. The application of the principles of good corporate governance (GCG) namely accountability, transparency, fairness, responsibility, independence, participation at this time is needed by the company in order to survive and be strong in the face of increasingly tight and strong competition [14]. 
In this study, formulated research questions are whether business strategy and good corporate governance either partially or simultaneously affect the company's performance. The purpose of this study is to analyze business strategies and good corporate governance both partially and simultaneously influence the company's performance.

\section{Literature review}

\subsection{Business Strategy}

According to [13], business strategy is a strategy that focuses on improving the competitive position of a company or business unit product or service with a specific industry as well as market segmentation of the company or service business unit and also a very important thing because of seeing how the unit the business has an effect on the overall performance of the company.

\subsection{Good Corporate Governance}

According to [10], good corporate governance is a process and structure used by a company (Shareholders / Capital Owners, commissioners / Supervisory Board, and Directors) in enhancing business success and corporate accountability to keep in mind the interests of stakeholders and others, based on legislation and ethical values.

\subsection{Company Performance}

According to [6], company performance is a view of the state as a whole of the company over a certain period of time and is the result or achievement that is influenced by the company's operational activities in utilizing the resources owned.

\section{Methodology}

\subsection{Population and Research Sample}

The population in this study were the heads of departments departments of all companies in the basic industrial and chemical sectors in Bandung Raya totaling 46 people. The company name can be seen in Table 1 .

Table 1: List of companies' name

Table 1: List of companies' name
\begin{tabular}{|c|c|c|}
\hline No. & Companies & Amount \\
\hline 1 & PT Kertas Padalarang & 13 People \\
\hline 2 & PT Papyrus Sakti Paper Mill & 9 People \\
\hline 3 & PT Masterindo Logam Teknik Jaya & 13 People \\
\hline 4 & PT Bozetto Indonesia & 11 People \\
\hline \multicolumn{2}{|c|}{ Total } & 46 People \\
\hline
\end{tabular}

The sampling technique used in this study is Nonprobability sampling, which is census sampling as many as 46 people.

\subsection{Data Collection Techniques}

Data collection techniques used are:

1. Primary data, by way of: questionnaire

2. Secondary data, by means of: library research (library research) [5].

\section{Results and discussion}

\subsection{Business Strategy}

Business Strategies for several basic and chemical industry companies in Bandung Raya City (PT. Paper Padalarang, PT. Papyrus Sakti Paper Mill, PT, Masterindo Logam Teknik Jaya and PT. Bozetto Indonesia) are already good because they are supported by cost and differentiation leadership, this is in accordance with the theory put forward by [5] is a business strategy commonly used by companies is cost and differential leadership. Besides that, the data obtained from the distribution of questionnaires to 46 respondents regarding the business strategy showed good, because it obtained a score of 4.06 where 4.06 was in the interval $3.40-4.20$ in the good category. But from the results of the leadership questionnaire the cost of the company questionnaire in its operations reduced equipment costs and depreciation, obtained a high value for the answer less agree that is 8 people. Regarding the company questionnaire using the computerized route to reduce the transportation load obtained a high value for the answer is less agree as many as 10 people. This indicates that the company has not fully been able to use a management information system that can reduce equipment costs, depreciation and transportation costs. But overall for cost leadership in a number of basic and chemical industry companies in Bandung Raya (PT. Paper Padalarang, PT. Papyrus Sakti Paper Mill, PT, Masterindo Logam Teknik Jaya and PT. Bozetto Indonesia) are in the good category, because the score is 4.18 where 4.18 is in the interval $3.40-4.20$ in the good category.

\subsection{Good Corporate Governance}

Good corporate governance for a number of basic and chemical industry companies in Bandung Raya City (PT. Paper Padalarang, PT. Papyrus Sakti Paper Mill, PT, Masterindo Logam Teknik Jaya and PT. Bozetto Indonesia) has been good because it is supported by good principles corporate governance includes transparency, accountability, responsibility, independence, fairness and equality. In addition, the data obtained from the distribution of questionnaires to 46 respondents regarding good corporate governance showed good, because it obtained a score of 4.08 where 4.08 was at interval 3, $40-4.20$ in good category. But from the results of the independent questionnaire regarding questionnaires there was no outside intervention that obscured the company's mission and vision, obtained high scores for answers that were less agreeable as many as 5 people. This indicates that the company is still interfering with outsiders who obscure the company's mission and vision. But overall for independence in some basic and chemical industry companies in Bandung Raya (PT. Kertas Padalarang, PT. Papyrus Sakti Paper Mill, PT. Masterindo Logam Teknik Jaya and PT. Bozetto Indonesia) are in the good category, because the score is 4,19 where 4.19 were in intervals of $3.40-4.20$ in the good category.

\subsection{Company Performance}

The Company's performance in several basic and chemical industry companies in Bandung Raya City using the Balance Scorecard approach is good because of the existence of a financial perspective, customer perspective, internal business process perspective, and learning and growth perspective. This is in accordance with the theory put forward by [7] that the performance of a company can be measured by the Balance Scorecard approach including financial perspective, customer perspective, internal business process perspective, and learning and growth perspective. The data from the sample of 46 people or respondents on the business strategy showed that the results in this research was 4.20 , whereas 3.40-4.20 interval is on good category. But from the results of the financial perspective questionnaire 
about the company's income questionnaire has increased each year, obtained a high value for the answers less agree as many as 9 people. This indicates that the company's opinion is not increasing every year. But as a whole for the financial perspective of some basic industrial and chemical companies in Bandung Raya (PT. Paper Padalarang, PT. Papyrus Sakti Paper Mill, PT, Masterindo Logam Teknik Jaya and PT. Bozetto Indonesia) are in the good category because the score is 4.02 where 4.02 is in the interval $3.40-4.20$ in the good category.

\subsection{Effect of Business Strategies on Company Performance}

Based on the results of the research shows that business strategies affect the company's performance. This research is supported by the research of [2] showing that business strategies affect the company's performance. In [4] research shows that integrated business strategies where high cost leadership indicators and high differentiation can affect company performance. According to [9] states that companies that have cost and differentiation leadership business strategies that are at the same time better than companies that only use one strategic indicator. In [13] state that business strategies focus on improving the competitive position of a company or business unit product or service with a specific industry as well as market segmentation that the company or service business unit is also very important because of seeing how the business unit has an effect on the overall performance of the company.

\subsection{Effect of Good Corporate Governance on Company Performance}

Based on the results of the study showed that good corporate governance affects the company's performance in terms of company performance. This research was supported by previous research conducted by [12]. This research is supported by previous research conducted by [12] that good corporate governance affects the company's performance and can improve the performance and profit of the company and can attract investors to invest in the company, an investor to invest in a company seen from company profits obtained as well as the implementation of good corporate governance in the company. According to [14] that good corporate governance is getting better so that it can improve the company's performance and can attract investors to invest or invest in the company. In general, investors to invest in a company will usually see good corporate governance and increasing company performance.

\subsection{Effect of Business Strategy and Good Corporate Governance on Company Performance}

Based on the results of the study showed that business strategies and good corporate governance affect the company's performance Detailed submission guidelines can be found on the journal web pages. All authors are responsible for understanding these guidelines before submitting their manuscript.

\section{Conclusion}

\subsection{Conclusion}

Based on the results of the research, it can be concluded as follows:

1. Business strategies affect the company's performance.

2. Good corporate governance affects the company's performance.

3. Business strategy and good corporate governance affect the company's performance.

\subsection{Recommendations}

Based on the results of the study found things that can provide input and improvements are as follows:

1. The company can fully use management information system that can reduce equipment costs, depreciation and transportation.

2. The company must not interfere with outsiders who obscure the company's mission and vision

3. The company's income must be increased every year.

\section{References}

[1] Balsam, S., Fernando, G. D., \& Tripathy, A. (2011). The Impact of Firm Strategy on Performance Measures Used in Executive Compensation. Journal of Business Research, 64, 187-193.

[2] Banker, R. D., Mashruwala, R., \& Tripathy, A. (2014). Does a differentiation strategy lead to more sustainable financial performance than a cost leadership strategy? Management Decision, 54,872-896.

[3] Brigham, E. F., \& Daves, P. R. (2014). Intermediate financial management. Cengage Learning.

[4] Chan, R. Y. K., \& Wong, Y. H. (1999). Bank generic strategies: Does Porter's theory apply in an international banking center. International Business Review, 8, 561-590.

[5] Hansen, D. R., \& Mowen, M. M. (2013). Akuntansi Manajerial. Salemba Empat.

[6] Helfert, E. A. (1996). Teknik Analisis Keuangan. Erlangga.

[7] Kaplan, R., \& Norton, D. (2000). Menerapkan Strategi Menjadi Aksi Balance Scorecrad. Erlangga.

[8] Parnell, J. A. (2010). Strategic Clarity Business Strategy and Performance. Journal of Strategy and Management, 3, 304-324.

[9] Pearce, J. A., \& Robinson, R. B. (2000). Formulation, Implementation, and Control of Competitive Strategy. McGrawHill.

[10] Sutedi, A. 2012. Good Corporate Governance. Sinar Grafika.

[11] Maria, R. (2013). Pengaruh Penerapan Good Corporate Governance terhadap Kinerja Keuangan Perusahaan. BEI Jurnal Ilmu \& Riset Akuntansi, 2(1), 73-89.

[12] Irma, Yeni, Noorina, \& Muktiyanto, H. A. (2015). The Effect of Good Corporate Governace Mechanism to Firm's Performance (Empirical Study of Manufacturing Firms Listed on IDX). International Journal of Applied Business and Economic Research, 13(7), 4849-4866.

[13] Wheelen, T. L., Hunger, J. D., Hoffman, A. N., \& Bamford, C. E. (2015). Strategic Management and Business Policy. Pearson Education.

[14] Daniri, M. A. (2014). Lead by GCG. Gagas Bisnis Indonesia. 